\title{
Epidemiological Aspects of Nicotinism Among Students of Antananarivo Suburban High School (Madagascar)
}

\author{
Narindrarimanana Avisoa Randriamihangy, \\ University of Mahajanga, Cardiology department, \\ Mahavoky Atsimo Teaching Hospital, Mahajanga, Madagascar \\ Raphael Fidelis Randrianarivo, \\ University of Mahajanga, Neuro-psychiatry department, \\ PZAGA Teaching Hospital, Mahajanga, Madagascar \\ Xavier Delmas Milijaona, \\ University of Antananarivo, Cardiology department, \\ JRB Teaching Hospital, Antananarivo, Madagascar \\ Rado Olivier Rakoto Sedson, \\ University of Toamasina, Cardiology department, \\ Morafeno Teaching Hospital, Toamasina, Madagascar \\ Solofonirina Rakotoarimanana, \\ University of Antananarivo, USIC, JRB Teaching Hospital, \\ Antananarivo, Madagascar \\ Nirina Rabearivony, \\ University of Antananarivo, Cardiology department, \\ JRB Teaching Hospital, Antananarivo, Madagascar
}

Doi: 10.19044/esj.2018.v14n12p297 URL:http://dx.doi.org/10.19044/esj.2018.v14n12p297

\begin{abstract}
Introduction: Nicotinism is of world-wide growing concern among adolescents. The goal is to describe the epidemiological aspects of nicotinism among Antananarivo suburban high school students. Methods: This is a descriptive and analytical cross-sectional study conducted in 2015 through a cluster sampling. A standardised, anonymous self-completion questionnaire was given to 903 high school students. Results: We enrolled 901 students. The prevalence of students who experimented with tobacco use was $46.3 \%$ next to $11.7 \%$ of active smokers . Among active smokers, $47.6 \%$ were non-dependent, $14.3 \%$ slightly dependent, $29.5 \%$ moderately dependent and $6.7 \%$ strongly dependent on tobacco. The motive of $70.3 \%$ of smokers was to test tobacco. Among former smokers $72.7 \%$ stoped smoking for fear of the drawbacks of tobacco-related diseases.
\end{abstract}


Fear of heart disease $(p=0.004)$ and cancer $(p=0.008)$ was significantly associated with non-smoking status. Female gender $(\mathrm{p}=0.000$, OR 0.261 [0.164-0.415], 95\% IC) and having been informed on tobacco consequences $(p=0.003$, OR $0.401[0.213-0.753,95 \%$ IC] were protecting factors against tobacco use. The existence of a smoking circle was a risk factor of being a smoker: close friend ( $p=0.000$, OR 2,677 [2,027-3,534], 95\% IC), cousin ( $p$ $=0.002$, OR 1,529 [1,174-1,993], 95\% IC), brother/sister $(\mathrm{p}=0.023$, OR 1,478 [1,054-2,072], 95\% IC). Conclusion: The prevalence of nicotinism is significant despite the current prevention measures. The influence of the smoking circle and education are paramount. An active participation of nonsmokers adolescents in passing the message or raising awareness could improve the outcomes because they have influence on their peers.

Keywords: Nicotinism, students, adolescents, epidemiology, Madagascar

\section{Introduction}

Nicotinism is one of the leading causes of preventable death in the world. It is known to cause various cancers. It is also the most common risk factor of cardiovascular diseases among young people. In fact, cigarette smoking leads to endothelial injury and dysfunction, an increased risk of thrombosis, atherogenic disease processes and cardiovascular events (Centers for Disease Control and Prevention, 2010).

Recent trends indicate a decline in age when children and adolescents start to smoke (Harrabi et al., 2002). The future of the tobacco epidemic depends on their attitude (Afifa et al., 2009).

In Malagasy previous studies, considerable variations of the prevalence rate of adolescent smoking were reported. We need a regular assessment so that anti-smoking measures may be more adapted to the current situation. In Antananarivo, the recent study on adolescent smoking was done in the urban area (Razakandisa, 2013). We conducted this study to describe the epidemiological aspects of nicotinism among high school students in the suburban environment where conditions may be different from that of urban areas.

\section{Methods}

We conducted a descriptive and analytical study from January to June 2015 in suburban high schools of Antananarivo which includes 3 districts: Antananarivo Atsimondrano, Antananarivo Avaradrano and Ambohidratrimo. Antananarivo Atsimondrano was drawn for the realization of our study. A cluster sampling was conducted with the maximum possible prevalence of 0.5 and a 95\% confidence interval. Sample size was calculated according to the formula (Giezendanner, 2012): 


$$
\mathbf{n}=\frac{\mathbf{t}^{2} \mathbf{p}(\mathbf{1}-\mathbf{p})}{e^{2}}
$$

n: sample size

t: confidence level $(t=1.96$ for $95 \%$ confidence $)$

p: maximum prevalence rate $(\mathrm{p}=0.5)$

e: margin of error $(\mathrm{e}=0.05)$

$$
=>\mathbf{n} 1=384
$$

With the effect of the sampling plan, we multiplied the result by two:

$$
=>\mathbf{n} \mathbf{2}=384 \times 2=768
$$

With the imponderable (the non-response error or the registration error): we increased the result by $5 \%$ :

$$
=>\mathbf{N}=768+768 \times 5 / 100=\mathbf{8 0 6 , 4}
$$

Among the 97 high schools of Antananarivo Atsimondrano (statistical database 2013-2014, Department of Statistics DPE / MEN), we drew lots: 2 public high schools, 4 private denominational high schools (2 Catholic schools and 2 others) and 3 non-denominational private high schools. We included all students who attended the survey and wishing to participate after receiving the necessary explanation. The questionnaire was completed with the presence of the investigator in the classroom. The investigator could thus intervene in case of request for explanation by the students. We excluded those who did not complete their questionnaire correctly.

A student who smokes regularly and answered "yes" to the question "are you currently a smoker?" was considered as a current smoker. A student who had smoked a cigarette, even once in his life, was considered to "have already smoked" (or "smoked before").

The Fagerström test was used to measure tobacco dependence. It is a standard instrument for assessing the intensity of physical addiction to nicotine. It contains six items that evaluate the quantity of cigarette consumption, the compulsion to use and dependance. The items are summed to yield a total score of $0-10$. The higher the total Fagerström score, the more intense is the patient's physical dependence on nicotine (Heatherton TF, Kozlowski LT, Frecker RC, Fagerstrom KO, 1991; American College of Chest Physicians, 2008).

We used the IBM ${ }^{\circledR}$ SPSS ${ }^{\circledR}$ Statistics 20 software for data processing. A bivariate analysis was performed to evaluate the risk of being a smoker with a $95 \%$ confidence interval. The association between variables was evaluated using the Khi-square test. The significance level was $p \leq 0.05$.

In ethical considerations, an authorization was obtained from the school's headmaster. Students gave their consent to participate in the survey and completed the questionnaire anonymously. 


\section{Results}

Out of the 903 distributed questionnaires, 901 (99.78\%) were completed correctly. Students' general characteristics are described in Table I. Mean age was 16.7 years (10-25).

Table I: General characteristics of high school students

\begin{tabular}{llll}
\hline & & $\mathrm{n}$ & $\%$ \\
\hline Age & Minor $(<18)$ & 647 & 71.8 \\
Gender & Major $(\geq 18)$ & 254 & 28.2 \\
& Male & 431 & 47.8 \\
\multirow{3}{*}{ High school status } & Female & 470 & 52.2 \\
& Public & 401 & 44.5 \\
& Private & 500 & 55.5 \\
& - Denominational & 319 & 35.4 \\
& - Non denominational & 181 & 20.1 \\
\hline
\end{tabular}

\section{Cigarette consumption}

The rate of students who smoked even once in their lifetime was $46.3 \%$ $(\mathrm{n}=417)$ with male predominance ( $66 \%$ of boys versus $27 \%$ of girls). Among them, 58 (14.14\%) smoked their first cigarette before the age of 10;187 (44.84\%) from 10 to 14 years and $171(41 \%)$ from 15 to 19 years.

The prevalence of current active smokers was $11.7 \%(n=105)$. Current smoking students were aged between 14 and 25 .

Determinants of smoking are cited in Table II and Table III.

\section{Tobacco dependance}

According to the Fagerström test, 50 (47.6\%) of the 105 current smokers were not tobacco dependent, 15 (14.3\%) were slightly dependent, 31 (29.5\%) moderately dependent, and 7 (6.7\%) strongly dependent.

Table II: Determinants of current smoking

\begin{tabular}{llllll}
\hline & & $\mathrm{n}$ & $\begin{array}{l}\text { Current } \\
\text { smoking }\end{array}$ & $\mathrm{p}$ & Odds Ratio \\
\hline Gender & Male & 431 & 79 & 0.000 & 0.261 \\
Age & Female & 470 & 26 & & {$[0.164-0.415]$} \\
& Major & 254 & 34 & $\mathrm{NS}$ & - \\
Marital status of parents & Minor & 647 & 71 & & \\
& Single & 130 & 17 & $\mathrm{NS}$ & - \\
& Biparental & 771 & 88 & & \\
High school status & Private & 500 & 51 & $\mathrm{NS}$ & - \\
& Public & 401 & 54 & & \\
Have you received & No & 395 & 57 & NS & - \\
informations on the & Yes & 339 & 41 & & \\
composition of tobacco? & & & & & \\
Have you received & No & 58 & 15 & 0.003 & 0.401 \\
informations on the & Yes & 677 & 83 & & {$[0.213-0.753]$} \\
consequences of tobacco? & & & & & \\
Are students punished if & No & 53 & 8 & NS & -
\end{tabular}




\begin{tabular}{|c|c|c|c|c|c|}
\hline \multirow{3}{*}{$\begin{array}{l}\text { they are caught smoking? } \\
\text { Are there regulations in } \\
\text { your high school that } \\
\text { prohibit smoking? }\end{array}$} & Yes & 848 & 97 & \multirow[b]{2}{*}{ NS } & \multirow[b]{2}{*}{ - } \\
\hline & No & 28 & 4 & & \\
\hline & Yes & 873 & 101 & & \\
\hline Is there an anti-smoking & No & 125 & 15 & NS & - \\
\hline law in Madagascar? & Yes & 776 & 90 & & \\
\hline
\end{tabular}

\section{Why did students smoke and why did they stop smoking?}

We asked the reason why the 417 students smoked: $293(70.3 \%)$ cited "to test tobacco", 68 (16.3\%) "influence of others", 19 (4.6\%) "fun", 12 (2.9\%) "conviction", 6 (1.4\%) "fashion", 3 (0.7\%) "prohibition" and 15 (3.6\%) "other reasons".

Three hundred and twelve high school students had stopped smoking for different reasons: $227(72.7 \%)$ because of the fear of tobacco-related diseases; $71(22.7 \%)$ because of the ban; $39(12.5 \%)$ say not tolerating tobacco ; $26(8.3 \%)$ stopped because of lack of money and $3(0.9 \%)$ cited other reasons. Many students cited more than one reason.

Table III: Influence of the smoking circle on student's nicotinism

\begin{tabular}{|c|c|c|c|c|c|}
\hline & & $\begin{array}{l}\text { Never } \\
\text { smoked }\end{array}$ & $\begin{array}{l}\text { Smoked } \\
\text { before }\end{array}$ & $\mathbf{p}$ & Odds Ratio \\
\hline Close friend & $\begin{array}{l}\text { Smoking } \\
\text { Non-smoking }\end{array}$ & $\begin{array}{l}130 \\
353\end{array}$ & $\begin{array}{l}207 \\
210\end{array}$ & 0.000 & $\begin{array}{l}2.677 \\
{[2.027-3.534]}\end{array}$ \\
\hline Father & $\begin{array}{l}\text { Smoking } \\
\text { Non-smoking }\end{array}$ & $\begin{array}{l}155 \\
329\end{array}$ & $\begin{array}{l}157 \\
259\end{array}$ & NS & - \\
\hline Mother & $\begin{array}{l}\text { Smoking } \\
\text { Non-smoking }\end{array}$ & $\begin{array}{l}50 \\
434\end{array}$ & $\begin{array}{l}52 \\
365\end{array}$ & NS & - \\
\hline Brother/sister & $\begin{array}{l}\text { Smoking } \\
\text { Non-smoking }\end{array}$ & $\begin{array}{l}76 \\
408\end{array}$ & $\begin{array}{l}90 \\
327\end{array}$ & 0.023 & $\begin{array}{l}1.478 \\
{[1.054-2.072]}\end{array}$ \\
\hline Teacher & $\begin{array}{l}\text { Smoking } \\
\text { Non-smoking }\end{array}$ & $\begin{array}{l}354 \\
130\end{array}$ & $\begin{array}{l}324 \\
93\end{array}$ & NS & - \\
\hline Cousin & $\begin{array}{l}\text { Smoking } \\
\text { Non-smoking }\end{array}$ & $\begin{array}{l}237 \\
247\end{array}$ & $\begin{array}{l}248 \\
169\end{array}$ & 0.002 & $\begin{array}{l}1.529 \\
{[1.174-1.993]}\end{array}$ \\
\hline Uncle/Aunt & $\begin{array}{l}\text { Smoking } \\
\text { Non-smoking }\end{array}$ & $\begin{array}{l}364 \\
118\end{array}$ & $\begin{array}{l}306 \\
111\end{array}$ & NS & - \\
\hline Grandparents & $\begin{array}{l}\text { Smoking } \\
\text { Non-smoking }\end{array}$ & $\begin{array}{l}200 \\
283\end{array}$ & $\begin{array}{l}185 \\
231\end{array}$ & NS & - \\
\hline
\end{tabular}

\section{Anti-smoking measures in Madagascar}

Smokers or non-smokers, $776(86.1 \%)$ students knew the existence of anti-smoking laws in Madagascar but 653 (72.5\%) admitted they did not know the means of fight against tobacco in the country. 
High school's discipline such as punishment brought fear to 552 $(61.3 \%)$ students but did nothing to $200(22.2 \%) ; 136(15.1 \%)$ did not care and laughed and 13 (1.4\%) students stood for other options (like thinking).

\section{Buying cigarettes}

Out of the 105 current smokers, $88(83.8 \%)$ bought cigarettes in grocery stores, $16(15.2 \%)$ on the street and $4(3.8 \%)$ in other places.

Eight hundred and sixty-two (95.6\%) students affirmed that the seller does not ask their age when they buy cigarettes.

To the question "with what money do you buy cigarettes?" 85 (80.9\%) answered "pocket money", 10 (9.5\%) "tobacco budget", 4 (3.8\%) "money for something else" and $6(5.7 \%)$ "others".

Table IV: Evaluation of the price of cigarettes by students

\begin{tabular}{llll}
\hline & Non-smokers & Current smokers & $\mathrm{p}$ \\
\hline Expensive & $124(15.6 \%)$ & $25(23.8 \%)$ & \\
Affordable & $114(14.3 \%)$ & $46(43.8 \%)$ & 0.000 \\
Cheap & $95(11.9 \%)$ & $16(15.2 \%)$ & \\
I do not know & $463(58.2 \%)$ & $18(17.1 \%)$ & \\
\hline
\end{tabular}

Table V: Existence of an impact of the means of fight against tobacco on students (Answer to the question: "Did the means of fight against tobacco have any impact on you?")

\begin{tabular}{ccc} 
& \multicolumn{2}{c}{ Impact } \\
\hline Increase price tobacco & $450(49.9 \%)$ & $451(50.1 \%)$ \\
Prohibition of the purchase of cigarettes & $312(34.6 \%)$ & $589(65.4 \%)$ \\
to younger than 18 years old & $298(33.1 \%)$ & $603(66.9 \%)$ \\
Cigarette package warning & $488(54.2 \%)$ & $413(45.8 \%)$ \\
\hline
\end{tabular}

Table VI: Knowledge of tobacco-related diseases

\begin{tabular}{llllllll}
\hline & Smoking & $\begin{array}{l}\text { Strongly } \\
\text { agree } \\
(\%)\end{array}$ & $\begin{array}{l}\text { Agree } \\
(\%)\end{array}$ & $\begin{array}{l}\text { Unsure } \\
(\mathbf{\%})\end{array}$ & $\begin{array}{l}\text { Disagree } \\
\mathbf{( \% )}\end{array}$ & $\begin{array}{l}\text { Strongly } \\
\text { disagree } \\
(\%)\end{array}$ & p \\
\hline Cardiac & No & 23.7 & 21.6 & 34.2 & 15.3 & 5.2 & 0.004 \\
diseases & Yes & 16.2 & 17.1 & 32.4 & 21 & 13.3 & \\
& & & & & & & \\
Vascular & No & 33.9 & 28.8 & 26.8 & 8.2 & 2.4 & NS \\
diseases & Yes & 21.9 & 37.1 & 24.8 & 12.4 & 3.8 & \\
Respiratory & No & 79.9 & 17.8 & 1.5 & 0.3 & 0.5 & NS \\
diseases & Yes & 68.6 & 26.7 & 3.8 & 0 & 1 & \\
Sexual & No & 5 & 7.7 & 30 & 30.7 & 26.6 & NS \\
diseases & Yes & 5.7 & 7.6 & 22.9 & 28.6 & 35.2 & \\
Cancers & No & 72.4 & 19.8 & 4.9 & 1.4 & 1.5 & 0.008 \\
& Yes & 57.1 & 28.6 & 11.4 & 1.9 & 1 & \\
\hline
\end{tabular}




\section{Discussion}

\section{Students who smoked before}

In our study, the prevalence rate of students who experimented with tobacco was $46.3 \%$ with a male predominance. In Madagascar, during the 2008 Global Youth Tobacco Survey (GYTS) conducted by WHO, this prevalence was $27 \%$ (42\% of boys and 15\% of girls) (Rakotoniaina, 2008). In Befinoana and Razanamihaja (2011) study in all Madagascar in 2011, 36.3\% of the 711 schoolchildren reported having already tasted tobacco and boys smoked twice as much as girls. In Senegal in the GYTS survey in 2007, the prevalence of students who experimented with tobacco was $12 \%$ (20\% of boys and 5\% of girls) (Samba, Mohamadou, Doulo, Aliou \& Khady, 2007). In France, however, with a high rate of $52 \%$ of adolescents who experimented with smoking in 2011, the predominance of girls (62\%) was striking (Minary et al., 2011). In Denmark, in 2007 in "the European School Survey Project on Alcohol and Other Drugs" (ESPAD), there was no difference in the prevalence between girls and boys (30\%) (Hibell et al., 2009). We see that the prevalence of those who have experimented with smoking among our teenagers seems to be increasing. Male dominance is found as in other African countries. In Madagascar, as in many African countries, the smoking of girls is more likely frowned upon. Actually, in our contry, the smoking girl is considered as a bad girl, poorly educated and rebellious. In contrast, in some western countries a smoking girl can be considered as an emancipated and confident girl (Kouassi et al., 2013).

\section{Current smoking}

On one hand, the prevalence of active current smoking was $11 \%$ in our study versus 12\% in urban Antananarivo in 2013 (Razakandisa, 2013), 19\% in all of Madagascar in 2008 (GYTS survey) (Rakotoniaina, 2008), 5.1\% in the whole island in 2011 in schools (Befinoana \& Razanamihaja, 2011) and 6.59\% among high school students in Mahajanga in 2014 (Randriamihangy, Adamo Ben Allaoui, Raveloson \& Raharimanana, 2016). It was 13\% in Dakar in 2011 (Faye, Seck, Seye Ndiaye, Ndiaye \& Tal-dia, 2011), 12\% in South Africa (GYTS 2011) (WHO, 2011), 9\% in the 2013 GYST in Algeria (WHO, 2013). On the other hand, this prevalence during high school years was $30.8 \%$ in France in 2011 (Spilka \& Nézet, 2013) and 32\% in Denmark in 2007 (Hibell et al., 2009). Thus, the prevalence of smoking in Africa were closer to ours with a lower rate than that of European countries. The prevalence of active smoking in suburban areas of Antananarivo was not far from that of the urban area two years earlier.

\section{Influence of smoking circle}

The influence of the smoking circle on the increased risk of smoking, 
especially smoking teanagers (close friend, brother/sister, cousin), was found in our study (Table III). In Senegalese schools, smoking students had a close friend who smoked in 29\% of cases (Faye et al., 2011). According to the study by Hutchinson, having a smoking best friend increased the chance of being a smoker by 5 times (Hutchinson, Richardson \& Bottorff, 2008). According to Lalonde, having smokers among his best friends was probably the strongest and most regularly identified predictor of smoking among 14- to 18-year-olds (Lalonde \& Heneman, 2004).

\section{Tobacco dependence}

We found that $52 \%$ of active smokers were tobacco addicts and 7\% were highly dependent. In Senegal in $2011,2 \%$ of pupils were highly dependent (Faye et al., 2011). In France, in 2010, in the TABADO program, $30 \%$ of daily smokers aged 17 to 18 were highly dependent on tobacco (Minary et al, 2010). Tobacco dependence can vary considerably as it depends on several factors including the importance of smoking and the sensitivity of the adolescent.

\section{Why did students smoke and why did they stop smoking?}

The motive of smokers students reflects the importance of the influence of others. This has also been found by other authors (Afifa et al., 2009).

The main causes of tobacco consumption cessation were fear of tobacco-related diseases. The literature also reports it (Afifa et al., 2009; Chabrol et al, 2000). But awareness of tobacco-related diseases seems insufficient (Table VI). The students easily cited respiratory diseases then cancers. In contrast, the association of tobacco with cardiovascular, sexual and other diseases was much less well known, as elsewhere (Faye et al., 2011). This probably requires revisions in the anti-smoking messages.

\section{Anti-smoking measures in Madagascar}

Most of the students found that the means of fight against tobacco had no impact on them (Table V). Nevertheless, sanctions scared $61.3 \%$ of all participants. Students bought their cigarettes in grocery stores without being refused despite their age. Actually, sellers rarely asked their age. This situation has hardly changed since the 2008 GYTS Report in Madagascar (Rakotoniaina, 2008) and even the 2007 GYTS Global Survey (Warren et al., 2007). Students had unrestricted access to tobacco as the majority of antismoking laws were not enforced. Moreover, the price of cigarettes is not a significant barrier for youth, as $59 \%$ of high-school smokers found it's price to be either affordable or cheap (Table IV), while young people are sensitive to the price of cigarettes (Befinoana \& Razanamihaja, 2011). The inefficiency 
of adolescent tobacco control is well known in Africa and Europe (WHO, 2013). In France, only the increase in the price of tobacco had significantly changed young people's tobacco consumption (Bogdan et al., 2010). It seems that the most effective way is to make access to smoking impossible for teenagers.

\section{Limitations of the study and future study plan}

First, the student's intellectual level varies from one class to another and each student has his own personality. Thus, possible biases could have been eliminated by personal interview. But personal interview is not compatible with the respect for anonymity.

Then, in Madagascar, a significant proportion of adolescents are no longer in school and are therefore not accessible with this type of survey. Thus, in order to have a more accurate assessment of adolescent smoking, a study among those who left school too early is required. Indeed, the fight against smoking should also concern them.

\section{Conclusion}

The prevalence of nicotinism among suburban high school students in Antananarivo is worrying and similar to that of the urban area. Most of tobacco control measures seem ineffective. Given the influence of the smoking circle, especially that of other teenagers, we suggest an active anti-smoking strategy involving non-smoking teenagers.

\section{References:}

1. Afifa, AK., Moncef, C., Najet, BA., Hayet, D., Nabil, O., Mohamed, TM. et al. (2009). Le tabagisme chez les collégiens de la région de Zaghouan. La Tunisie Méd, 87(9), 527-531.

2. American College of Chest Physicians (2008). Fagerström Test For Nicotine Dependance (FTND). Tobacco-Dependance Treatment Tool Kit, 3rd Edition.http://tobaccodependence.chestnet.org/patientassessment/nicotine -dependence-assessment-adults/fagerstrom-testfor-nicotine-dependence-ftnd-instructions-scoring-use/

3. Befinoana, Razanamihaja, N. (2011). Tabagisme et facteurs associés chez les adolescents scolarisés à Madagascar. Santé Publique, 6(23), 465-474.

4. Bogdan, M., Muller, D., Refabert, L., Dres, M. (2010). Tabagisme de l'adolescent. Rev Mal Résp Actual, 2, 358-361.

5. Centres for Disease Control and Prevention (US) (2010). How Tobacco Smoke Causes Disease: The Biology and Behavioural Basis for Smoking-Attributable Disease: A Report of the Surgeon General. https://www.ncbi.nlm.nih.gov/books/NBK53012/ 
6. Chabrol, H., Faury, R., Mullet, E., Callahan, S., Weigelt, A., Labrousse, F. (2000, Octobre). Study of nicotine dependence among 342 adolescent smokers. Archives de Pédiatrie, 7(10), 1064-1071.

7. Faye, A., Seck, I., Seye Ndiaye, AC., Ndiaye, P., Tal-dia, A. (2011, Juillet). Aspects épidémiologiques du tabagisme en milieu scolaire dakarois, au Sénégal. Méd Afr Noire, 587, 364-368.

8. Giezendanner, FD. (2012). Taille d'un échantillon aléatoire et Marge d'erreur. Paris; 2012. 32 p.

9. Harrabi, I., Ghannem, H., Abdelaziz, AB., Gaha, R., Trabelsi, L., Lazreg, F. et al. (2002). Tabagisme en milieu scolaire à Sousse. Rev Mal Résp, 19(3), 311-314.

10. Heatherton, TF., Kozlowski LT., Frecker RC., Fagerstrom KO. (1991). The Fagerstrom Test for Nicotine Dependence: a revision of the Fagerstrom Tolerance Questionnaire. Br J Addict, 86, 1119-1127.

11. Hibell, B., Guttormsson, U., Ahlström, S., Balakireva, O., Bjarnason, T., Kokkevi, A. et al. (2009). Substance Use Among Students in 35 European Countries. The 2007 ESPAD Report. Stockholm: The Swedish Council for Information on Alcohol and Other Drugs (CAN); 2009.

12. Hutchinson, PJ., Richardson, CG., Bottorff, JL. (2008, Fevrier). Emergent Cigarette Smoking, Correlations with Depression and Interest in Cessation among Aboriginal Adolescents in British Columbia. Rev Canadienne de Santé Publique, 99(5), 418-422.

13. Kouassi, B., Ngom, A., Godé, C., Horo, K., Ahui, B., N'Guessan, AJ. et al. (2013). Tabagisme féminin en milieu africain. Rev Epid Santé Publique, 6(1), 278-283.

14. Lalonde, M., Heneman, B. (2004, Octobre). La prévention du tabagisme chez les jeunes. Institut national de santé publique Québec. Octobre 2004. http://www.inspq.qc.ca.

15. Minary, L., Acouetey, DS., Bohadana, A., Wirth, N., Martini, H., Zmirou-Navier, D. et al. (2010). Aide au sevrage tabagique pour les adolescents apprentis : le programme TABADO. Rev Mal Resp, 27(7), 663-666.

16. Minary, L., Martini, H., Wirth, N., Thouvenot, F., Acouetey, S., Maire, C. et al. (2011). Caractéristiques du tabagisme chez les adolescents en Centre de formation des apprentis. Rev Epid Santé Publique, 5(9), 270276.

17. Rakotoniaina, JP. (2008). Rapport de l'enquête nationale sur le tabagisme chez les jeunes en milieu scolaire à Madagascar. Global Youth Tobacco Survey (GYTS), 1-13.

18. Randriamihangy, NA., Adamo Ben Allaoui, Raveloson, F., Raharimanana, RN. (2016). Prevalence du tabagisme et profil des 
élèves fumeurs aux lycées de Mahajanga I en 2014. European Scientific Journal, 12(23), 298-308.

19. Razakandisa, AS. (2013). Attitudes et comportements des lycéens d'Antananarivo face au tabagisme [Thèse]. Médecine Humaine: Antananarivo; 2013.99p.

20. Samba, CS., Mohamadou, LM., Doulo, D., Aliou, A., Khady, D. (2007). L'enquête sur le tabac chez les adolescents en milieu scolaire au Sénégal. Sénégal : OMS 2007.

21. Spilka, S., Le Nézet, O. (2013, Novembre). Alcool, tabac et cannabis durant les « années lycée». OFDT Tendances, 89, 1-8.

22. Warren, CW., Jones, NR., Peruga, A., Chauvin, J., Baptiste, JP., Costa de Silva, V. et al. (2007). Global Youth Tobacco Surveillance 20002007. WHO 2007.

23. World Health Organization. (2011). Global Youth Tobacco Survey South Africa.

24. World Health Organization. (2013). Global Youth Tobacco Survey (GYTS) Algeria. 